tendered to Mr. and Mrs. Elchelberger for thus generously furnishing us rooms in their hotel.

The "Old Folks" favorite song, "Auld Lang Syne," was then sung in full chorus-Mrs. W. C. Brewster presiding at the piano-all standing with joined hands, W $\mathrm{m}$. Gordon, Esq., a native of the land of Burns, lining the words.

On motion, adjourned until next quarterly meeting, to bo held at the same place.

WM. LEFFINGIVELL, President.

P. JACKson, Secretary.

\title{
PIONEER SETTLERS' FESTIVAL OF SCOTT COUNTT.
}

The Eighth Annual Festival of the Pinneer Settlers of Scott county was held at the Pennsylvania Honse last evening. This organization be it known, is made up of early seltlers of this county - those who cast their lot here previous to January 1st, 1841. The organization has been formed eight years, and its annual g therings are matters of considerable interest, and will undoubtedly continue to increase in isterest until the last one of the early settlers of our favored county holds the last annual meeting. So far, then, the Society has had seven Presidents. The insignia of their office is a gold headed, oak cane, which passes from one president to his successor from year to year. The names of the presidents thus far are as follows: Antoine Le Claire for two years; Ebeniezer Cook; Willard. Barrows; Duncan C. Eldridge; John Owens; James M. Buwling, and Harvey Leonard.

Promptly at the hour of seven o'clock last evening the pioneers, to the number of about two hundred, assembled in the spacious reception rooms of the Pennsylvania House, and the ceremonies of the evenin $x$ commenced. 
President J. M. Bowling took the chair and called the meeting to order. after which the Davenport Glee Club sang the beautiful quartette, "Al Together Again."

The President then delivered the valedic ory address, and owing to the unavoidable ahsence of the President elect, Harrey Leonard, the cane was transferred by Mr. Bowling to first Vice-President, James MeCosh, who received the same with appropriate remarks, after which "The Old House at Home" was sung by the Glee Club.

Hon. Jno. F. Dillon, orator of the evening, then took the stand and delivered the annual address, in which he conferred honor upon limself and the suciety.

The next in order was the singing of that popular and appropriate "Auld Lang Syne" by the Ola Settlers, the execution of which wan hearly and full of impressive melody. The "Old Settler" are all proficient in rocal music when this good old song is called ont.

The next important proceeding in order was the supper, to which all proceeded in good order, and after the invocation of Divine Blessing by the Rev. Father Pelamorgues, was assailed on all sides in a manner denoting excellent appetites and highly complimentary to the worthy hosts who provided it.

REGULAR TOASTS.

The Pilgrim Fathers of New England and the Pioneer Settlers of Iowa-one settled upon the rocky shores of the East, the other upon the broad prairies of the West; we are their descendants-may we emulate their virtues, and our children inherit the energy and enterprise of the "pilgrim pioneers"

Responded to by Rev. E. Mead.

The Last Log Cabin-like the pioneers of Iowa, fast going to decay.

Responded to by W. Barrows.

The first frame house in Scott County-where is it?

Responded to by G. L. Davenport, who stated it was on the 
Watkin's place above East Davenport, and was built in 1833. Iowa Soldiers - from Springtield to Shiloh, from Vicksburg to Savannah, they have left their dead on every battle-field and made a record so bright, that there is no higher honor than to be called an Iowa soldier.

Responded to by A. Sanders.

Pioneer Setllers' Association-the memory of its first President, Antoine Le Claire.

Scott County - the Weathersfield of the West; may her onions continue to grow until she challenges the world in their production.

Responded to by J. McCosh.

The Old Settlers then interested themselves for an hour or so in friendly intercourse, sociable chat, renewal of old aequaintance, etc., and at eleven o'clock the party joined once more in "Auld Lang Syue," as the closing exercises, after which, as in good ot d tashioned style, the meeting broke up early and the old folks songht their homes, all highly delighted with their eighth annual gathering, which all agreed was the most intere tir.g of any that has been held.

May the Oid Settlers long live to enjoy many more such happy and exceedingly appropriate re-unions.-Daver port Democrat, January 19, 1865. 
Copyright of Annals of Iowa is the property of State of Iowa, by \& through the State Historical Society of Iowa and its content may not be copied or emailed to multiple sites or posted to a listserv without the copyright holder's express written permission. However, users may print, download, or email articles for individual use. 